\title{
O tęsknotach poety \\ Myśli przez Ivana Hribovška podpowiedziane
}

\author{
JoAnNA PszczOlA \\ Uniwersytet Śląsi, Wydziat Filologiczny, ul. Grota-Roweckiego 5, \\ PL-41-205 Sosnowiec, joannapszczola@o2.pl
}

SCN IV/1 [2011], 111-122

Prispevek se osredinja na poezijo slovenskega vojnega pesnika Ivana Hribovška in na njegovo življenjsko zgodbo. Avtor je bil v domovini (pod komunistično oblastjo) prepovedan in zamolčan. Tako on kot njegova poezija sta bila deležna ignoriranja, saj se je Hribovšek odločil pridružiti »belim partizanom«; zaradi tega je bil obsojen izdajalstva. Ob tem je presenetljivo dejstvo, da v njegovi poeziji ne zasledimo politične note, temveč zgolj lirske refleksije o večnih literarnih motivih - Bogu, ljubezni, smrti in zemlji.

In this article the author deals with the poetry of the Slovenian war poet, Ivan Hribovšek, and his story. In his homeland (under communist rule) he was rejected and condemned to oblivion. He and his poetry were ignored because he decided to join the guerrillas during the war and was later accused of treason. What is most interesting about his poetry is that it is not political at all; rather, this poetry is a lyrical reflection on God, love, death and the Earth, the eternal motifs of literature.

Ključne besede: zemlja, Bog, življenje, smrt, ljubezen, vojna, svoboda, nujnost, vrnitev iz tišine

Key words: the Earth, God, life, death, love, war, freedom, necessity, come back from the silence

„[...] ta część [poety], która zwycięży śmierć, to tekst.

Zmartwychwstać znaczy być czytanym."

R. Przybylski, To jest klasycyzm

Literatura słoweńska, jak pozostałe jugosłowiańskie i wiele innych, które w powojenne stadium swego rozwoju wkraczały w sytuacji dotkliwego ograniczenia twórczej swobody, dostarcza wielu przykładów konfliktu między doraźnie zwycięską ideologią polityczną a jej przeciwnikami, czy nawet nie dość gor- 
liwymi, bezkrytycznymi wyznawcami - jak Edvard Kocbek, w latach wojny aktywista Frontu Wyzwolenia, ${ }^{1}$ w okresie wczesnej młodości socjalistycznej republiki przedstawiciel jej społeczno-politycznych elit, a po opublikowaniu tomu wojennych, personalistycznie i egzystencjalistycznie motywowanych nowel Strah in pogum (1951) ogłoszony jej wrogiem, który inteligenckie rozterki moralne przypłacił kilkunastoletnią banicją ze słoweńskiego życia publicznego, przede wszystkim artystycznego - co dla twórcy szczególnie uciążliwe. Na jeszcze dłuższą i bezwzględną banicję, będącą aktem politycznej zemsty za udział we wrogiej komunistycznej partyzantce formacji „obrońców domu”, został pośmiertnie skazany France Balantič. Najdrastyczniejsze skutki konfliktu między polityką a literaturą dotknęły jednak Ivana Hribovška, którego polityka - swoim zbrojnym ramieniem - najpierw fizycznie unicestwiła, a potem wrzuciła jego poezję do orwellowskiego „grobu niepamięci”.

Zanim jednak możliwa stała się publikacja twórczości poetyckiej Ivana Hribovška w ojczyźnie, za sprawą ówczesnego mentora słowiańskości na emigracji Tine Debeljaka, Słoweńska Akcja Kulturalna w dwudziestą rocznicę tragedii w lasach kočevskich ${ }^{2}$ decyduje się na przedstawienie szerszej publiczności zbiorku, nieznanego dotąd słoweńskiego pisarza. W słowie wstępnym do publikacji Pesem naj zapojem autorstwa Tine Debeljaka czytamy: „Zbirka je zato v nekem smislu zavestno prigodna, toda še bolj zavestno pa hoče biti pionirsko dejanje: iz množičnega groba doslej neznanega vojaka naj dvigne po čudni usodi v slovensko književno zgodovino mladeniča, o katerem moramo reči danes, ko ga predstavljamo, to, kar je slovaški pesnik Dilong zavpil v svet ob našem Balantiču: zabili basnika - Ubili so pesnika!" (podkr. moje J. P.) (Debeljak 1965: IX).

\footnotetext{
${ }^{1}$ Niniejszy artykuł, w nieco zmienionej formie jest częścią monografii wydanej w bieżącym roku pod tytułem Tajemnica transcendencji. Duchowość poezji Ivana Hribovška (Pszczoła 2011: 7-23). Front Wyzwolenia - (słow.) „Osvobodilna Fronta - politična organizacija in množično gibanje Slovencev 1941-52. OF je že 1941 sestavila program; končno ga je izrazilo 9 točk. [...] Ki so med drugimi izražale demokratične težnje slovenskega naroda: neusmiljen oborožen boj proti okupatorjem in njihovim sodelavcem za osvoboditev Slovenije, združitev vseh Slovencev, itd. OF je bila posebnost v jsl. partizanskem gibanju in širše." (Enciklopedija Slovenije 1994: 199-202). W Poetyckiej kosmogonii Edvarda Kocbeka Joanna Sławińska pisze: „Z perspektywy trzydziestu lat ocenia [...] Kocbek, pozycję ugrupowań chrześcijańskich w ramach Frontu Wyzwolenia, formułuje swój krytyczny stosunek do współczesnego społeczeństwa i zbiurokratyzowanej partii. Największe jednak wzburzenie wywołuje jego wypowiedź dotykająca nader bolesnego dla Słoweńców problemu. Był nim los formacji tzw. ,domobrancev', zlikwidowanych przez partyzantów w 1945 roku w lasach Kočevskiego Rogu. Słowa Kocbeka są po raz pierwszy głośno sformułowanym oskarżeniem o zbrodnię (które jest równocześnie samooskarżeniem) i żądaniem ekspiacji” (Sławińska 1993: 15).

${ }^{2}$ Hasło: Kočevski Rog: ,[... [ Po končani vojni so v nekaterih kraških jamah K. R. usmrtili nekaj tisoč slovenskih domobrancev in tudi pripadnikov drugih jsl. narodov. [...] Najbolj znani sta množični grobišči v jamah pod Macesnovo goro in pod Krenom" (Enciklpedija Slovenije 1991: 184).
} 
Celem eseju jest krytyczna prezentacja twórczości poetyckiej Ivana Hribovška, oraz jej artystycznej wartości. W pierwszej kolejności jednak, praca ta, jest próbą dotarcia do autentycznych sensów jego poezji, nierozerwalnie splecionej z biograficznym doświadczeniem kruchej, wrażliwej osobowości po Heideggerowsku ,wrzuconej” w wir historii. Ponieważ w ostatnim czasie literatury na powyższy temat przybywa, prawdopodobnie nasz wkład w tę dziedzinę nauki w wielu, lub tylko, niektórych kwestiach nie będzie nowatorski, czy wręcz potrzebny. Żywimy jednakże nadzieję, że każda myśl i każda teza dopełnia, zawsze nie w pełni uchwyconą sylwetkę poety i jego czasu. Celowe zatem będzie przypomnienie kilku najistotniejszych faktów biografii poety, mających doniosły wkład w ewoluowanie i krystalizację jego artystycznego wizerunku.

Ivan Hribovšek urodził się w Radovljicy 19 czerwca 1923 roku w rodzinie Marii Erman i Janeza Hribovška. Był więc rok młodszy od innego wielkiej miary poety France Balantiča, obydwaj jednakże dożyli zaledwie dwudziestu dwóch lat. Cóż zatem możemy powiedzieć o krótkim życiu, interesującego nas, poety? Ojciec Ivana pracował jako urzędnik sądowy, matka zajmowała się wychowaniem czworga dzieci, dbając szczególnie o ich rozwój duchowy. Nie można mieć żadnych wątpliwości, że pierwsze lata życia poety i środowisko ludzi świadomie wierzących, w którym wyrastał miały na kształtowanie się jego duchowości przemożny wpływ.

Pierwsze brutalne wyrzucenie ze świata dzieciństwa w świat przedwczesnej dojrzałości i alienacji, nastąpiło po raz pierwszy wraz z rozpoczęciem nauki w szkole podstawowej, do której wstąpił jako społecznie napiętnowany, ze względu na złą kondycję finansową ubogiej rodziny. Jednakże od pierwszych klas wyrównywał, nierówności powstałe na materialnym poziomie, talentem i sumiennością, dzięki którym na cenzurkach błyszczały same najwyższe oceny, nie pozostawiając żadnych wątpliwości o konieczności dalszego kształcenia uzdolnionego młodzieńca. Pytanie dotyczyło raczej szkoły i miasta, do którego korzystniej byłoby chłopca posłać. „Osnovnošolsko spričevalo daje navedek, da je Hribovšek 26. junija 1934 uspešno opravil sprejemni izpit na realni gimnaziji v Kranju, zraven najdemo dokumentacijo, da je bil v šolskem letu 1934/35 vpisan v 1. b razred Škofijske klasične gimnazije v Šentvidu nad Ljubljano" (Hribovšek 1993: 78) - pisze France Pibernik wnikliwy badacz poezji ,przemilczanego" poety. Czyżby wybór szkoły stanowił dla rodziny aż tak istotny problem, że do ostatniej chwili trudno było podjąć decyzję? Ojciec, obawiając się wyzwolenia w chłopcu zbytniej niezależności, związanej z długotrwałymi dojazdami do krańskiego gimnazjum, zdecydował o kształceniu i (kształtowaniu światopoglądu) syna w szkole katolickiej. Matka prawdopodobnie nie poradziłaby sobie z gospodarstwem, opieką nad chorym mężem i wychowywaniem dorastających chłopców. Decyzja szybko przyniosła dobre rezultaty, zwłaszcza że, niedługo po jej podjęciu, Janez Hribovšek osierocił żonę i troje dzieci. Chłopcy zamieszkali wówczas w przyszkolnym internacie, pod dobrą opieką doświadczonych prefektów. Ivan Hribvšek przebywał tu jednak tylko do końca 1940 roku, był to bowiem rok „czystki” (określenie Tine Debeljaka) w 
szkole. Kiedy to wielu uczniom poradzono, by poszukali sobie nowego zawodu. Obydwaj bracia, bo także i młodszy France opuścili szkołę. Ivan wpisał się do Gimnazjum Klasycznego w Ljubljanie, gdzie z powodu wybuchu wojny, w kwietniu 1941, kontynuował naukę jedynie przez rok. Gdy Słowenię przecięła linia demarkacyjna, dzieląc kraj na niemiecką oraz włoską strefę wpływów, ${ }^{3}$ Hribovšek pozostał po stronie niemieckiej. Maturę zdał w niemieckiej szkole w Beljaku, by następnie udać się na studia klasyczne na uniwersytet wiedeński.

Z powodu słabego zdrowia został tymczasowo zwolniony z obowiązku służby wojskowej w wojsku niemieckim. Nie mogąc przystąpić jawnie do domobranów, ${ }^{4}$ został przez nich rzekomo siłą zwerbowany. Jego dowódca mówi o nim: „Vojak ni bil, a bil je med najbolšimi domobranci tako glede discipline na postojanki kakor na varnostnih pohodih ali v boju" (Debeljak 1965: X). Wspomina on także jego wieszczą przepowiednię, którą wypowiedział uciekając do Karyntii: „Gremo k Angležem, toda oni nas boda vrnili partizanom” (Debeljak 1965: X). Niestety była to prawda. Wiemy, że potem był uwięziony w szentwidzkiej kaplicy, w której wielokrotnie przedtem bywał, by się modlić i rozmyślać. Co się wydarzyło później, to raczej hipotezy aniżeli fakty. Prawdopodobnie uciekł i pomagał innym domobranom uwolnić się z niewoli, wkrótce został ponownie złapany i rozstrzelany nie wiadomo gdzie i kiedy, pewne jest jedynie to, że strzelano w tył głowy i pochowano go wraz z towarzyszami niewoli w zbiorowej mogile. Temat, przystąpienia poety do politycznie znienawidzonej organizacji, przedstawia w jego biografii, nierozerwalnie złączonej z sylwetką twórczą, rys istotny - będąc nośnikiem treści doniosłych przy prezentacji sylwetki twórczej poety - żołnierza - wart, by zajął się nim jakiś historyk (Debeljak 1965: X), jak pisze Tine Debeljak we wstępie do zbiorku poety.

Nas interesować będzie natomiast los Hribovška poety. Lata szkoły średniej to okres, w którym dzięki katolickiemu wychowaniu kształtuje się fundament etyczno-religijny światopoglądu młodzieńca, lecz co równie istotne, odsłania się wówczas charakterystyczny rys rodzącej się literackiej osobowości Hribovška - potrzeba aktywności twórczej oraz „głód metafizyki”. Działa wówczas w rozmaitych organizacjach uczniowskich, pisze i publikuje w szkolnych pisemkach. Juwenilia pisane pod pseudonimem Triglavski Feniks, datowane na

3 „Słowenię rozdzielono między Reszę i Włochy. Powołując się na sytuację z Austro - Węgier, włączono do rzeszy prowincje Krainy i Styrii. Teren ten podlegał bezpośredniemu zarządzaniu z Berlina. [...] We włoskiej strefie okupacyjnej powstała prowincja Lublany (Provincia di Lubiana) pod zarządem komisarza i współdziałającej z nim Konsulty, organem władzy cywilnej o bliżej nie sprecyzowanych uprawnieniach" (Madany 1988: 339).

4 „Domobranci” byli kolaborującą z hitlerowcami słoweńską formacją wojskową, utworzoną we wrześniu 1943 roku. Pod koniec wojny około 14 tysięcy domobranów oddało się w ręce aliantów, którzy odesłali ich z powrotem do Słowenii, gdzie w lasach Kočevskiego Rogu zostali skrycie zamordowani przez partyzantów titowskiego Frontu Wyzwolenia (OF). Wydarzenie to stanowi jedno z najtrudniejszych i najbardziej kontrowensyjnych zagadnień w słoweńskiej historii współczesnej. Por. także hasła: domobranstvo (Enciklpedija Slovenije 1991: 308). 
rok 1937 i opublikowane w pisemku „Jutranje zarje” mają klasyczny charakter. Poeta czerpie wzory z Prešerna, Župančiča, Kettego tworząc sonety, gazele, glosy. Rok kolejny przyniósł następne klasyczne publikacje z tą jednak różnicą, iż podpisane zostały one nazwiskiem twórcy. „Domače vaje” pismo starszych literatów szentwidzkiego gimnazjum redagowane przez Janeza Remica i Jožeta Brejca stało się kolejnym szczeblem w literackim dojrzewaniu młodego poety. Na październikowym spotkaniu pracowników i wspópracowników pisma Remic, który oceniał opublikowany numer zauważył: „Pesem Na oknih je enotna v svojem osnovnem razpoloženju. Moti nedognana podoba: [...] gledajo v neskončno melodijo [...], ki kaže Hribovška kot izrazitega vizualista, ki priteguje pojave vsega čutnega sveta v svet vidnega [...]. S Hribovškovo pesmijo smo dobili v Domače vaje nov izraz, ki ima v sebi vrednote, ki jih večno ekspresionistične ,Domače vaje' skoraj ne pomnijo" (Pibernik 1993: 86).

Ten okres literackiego rozwoju słoweńskiego poety, charakteryzuje się intensywnym rozwojem warsztatu twórczego - jego poezja nabywa pierwszych rysów indywidualności, chociaż wciąż jeszcze spotkać można gdzieniegdzie wpływ poetów doby słoweńskiej moderny. Prawdziwie zachwyca się koncepcjami twórczymi dwóch czołowych poetów chrześcijańskich: Antona Vodnika i Edvarda Kocbeka. Zachwyt Vodnikowym eteryczno-religijnym światem, niebawem ustał gdy okazał się nie być prymarnym światem Hribovška, podobnie rzecz się miała z fascynacją ekspresjonizmem, która także okazała się być efemeryczna. Trwałą fascynacją i wiernością obdarzył poeta natomiast zjawisko historycznoliterackie, którego „ojcem chrzestnym” na gruncie słoweńskim został Edvard Kocbek, mowa o „nowej rzeczywistości”. Joanna Sławińska, autorka pracy poświęconej, największemu autorytetowi moralnemu powojennej Słowenii, zauważa: „Wyjątkowość debiutu Kocbeka dostrzegła także współczesna poecie krytyka. [...] Tomik od razu wzbudził spore zainteresowanie, choć jak wynika z przekazów historycznoliterackich - częściej bywał argumentem w szerszej dyskusji na temat młodej literatury słoweńskiej niż obiektem krytycznych analiz czy interpretacji. [...] Najważniejszy krytyk i ideolog owej generacji literackiej, France Vodnik, określił tomik Kocbeka jako dowód na zauważalną zmianę orientacji literackiej ,od skrajnego spirytualistycznego ekspresjonizmu' w kierunku ,uduchowionej rzeczywistości', dzięki czemu, jak sądził, słoweńska liryka odnalazła znów kontakt z obiektywnym, realnym światem" (Sławińska 1993: 21). Nie cała ówczesna krytyka była jednomyślna, lecz ze względu na myśl przewodnią eseju nie będzie ona stanowić prymarnego problemu niniejszej rozprawy. Faktem jest natomiast, że nowy kierunek w literaturze znalazł od razu, spragnionych novum naśladowców, jednym z nich był Ivan Hribovšek. W wystąpieniu na temat poezji Vodnika, ekspresjonizm określa on jako „zjawisko przemijające w [...] literaturze", w którym znalazł wiele negatywnych stron jak: ucieczkę od życia, patetyczną leksykę, niezbyt zdyscyplinowaną formę. W innym miejscu zarzuca ekspresjonizmowi, iż „obrnil se je proti človeku, ker poudarja samo duha. Duh ga je zastrupil, zato je moral umreti" (Pibernik 1993: 92). Nowa rzeczywistość proponuje powrót do przedmiotów, nie do ich naturalistycznych wyglądów, lecz do ich rzeczywistości metafizycznych. 
Poeta mając przed sobą Kocbekową Ziemię (Zemljo) sam próbuje konstytuować indywidualne rysy swej poetyki, która jest bliższa rzeczywistości materialnej niż u Kocbeka, lecz tym samym ,łapczywiej” poszukuje wymiarów duchowych. Twórczość Ivana Hribovška dostarcza wielu przykładów; jak choćby Prošnja pesem, Pastirji, Brzojavni drogovi v dolgi vrsti, w których można wyśledzić tę nową właściwość poetyki słoweńskiego poety, wiersz Jutro stanowi doskonałą egzemplifikację przeplatania się pierwiastka materialnego z potrzebą duchowej konstatacji:

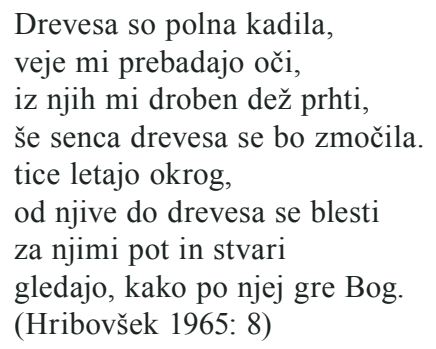

Fundamentalne znaczenie dla ewolucji tak osobowości, jak i sylwetki twórczej poety miał pobyt w Jelowicy, domu letnim dobrze sytuowanej rodziny Resmanów, gdzie oprócz ciepła i sympatii domowników spotkał swoją pierwszą i jedyną przyjaciółkę, powiernicę swej twórczości oraz wielką niespełnioną miłość. Anica Resman, bo o niej tutaj mowa, stała się tyle mecenasem, co i muzą młodego poety: swój pierwszy tomik Pesmice zadedykował Čudoviti priateljici Anici Resman v spomin in zahvalo. V Radovljici, 20. avgusta 1939. Ivan Hribovšek. Tomik obejmował dwadzieścia osiem wierszy rozdzielonych w cztery cykle: Žarki me božajo, Tesnoba teče mi skoz grlo, V usta se mi vsipljejo cvetovi, Čez obraz polzi mi kri. Cykl pierwszy jest jakby dokumentem fascynacji poety „nową rzeczywistością”, łączy realistyczne przeżycie świata z przeżyciem metafizycznym (duchowym). Według Franceta Pibernika: „Prvi cikel Žarki me božajo je vsekakor najbolj zanimiv. V njem nosijo težo pesmi, ki so izšle iz Kocbekove Zemlje in ki jih imenitno predstavlja predstavlja pesem Jutro. Iz nje izžareva poduhovljenost predmetov in uravnana, z ničimer obremenjena svetloba tega sveta" (Pibernik 1993: 99). Ważnym motywem tej twórczości - impresjonistycznym refleksem - jest przyroda, ze swoją wewnętrzną antynomią światła i cienia, na której tle rozgrywają się egzystencjalne problemy człowieka współczesnego.

Droga literackiego rozwoju Hribovška biegła identycznymi tropami jak droga wszystkich innych uczniów gimnazjum w Szentwidzie, mianowicie jako debiutanci współtworzyli oni pisemko młodych uczniów „Jutranje zarje”, jako uczniowie starszych roczników pisywali do pisma „Domače vaje”.

Szeregi szentwidzkiego gimnazjum obfitowały w zdolnych i obiecujących poetów jak: Jože Brejc, Janez Remic, Franc Peršin, wsród których piątoklasista Ivan Hribovšek był najmłodszy. Kolejnym zaś etapem jego literackiego rozwoju był „Dom in svet”, w którym to piśmie redagowanym przez Tine Debeljaka, Remic, najsilniejsza osobowość wśród młodych literatów i reszta publikowali 
swą poezję. Faktem, o doniosłym znaczeniu dla kształtowania sylwetki twórczej młodego poety, urzeczonego personalizmem chrześcijańskim był kontakt i współpraca z Edwardem Kocbekiem i „Dejanjem”. Rok 1940 przynosi kolejne publikacje wierszy debiutanta Ura i Rast, tym razem w renomowanym piśmie założonym przez Kocbeka. „Razen teh dveh pesmi mi ni ničesar znanega iz njegovega nastopanja $\mathrm{v}$ javnosti pred drugo svetovno vojno. Verjetno bi natančni pregled ,Mentorja', ,Mladike' in drugih listov utegnil odkriti pod raznimi pseudonimi njegovo avtorstvo. [...] Vsekakor je bil tiskan vsaj eno leto prej kot eno leto starejši Balantič" - pisze Tine Debeljak w słowie wstępnym do Pesem naj zapojem (Debeljak 1965: XII). Zbiorek Pesmice przygotowany przez 16 letniego poetę w 1939 roku zachował się do dziś. Podobnie jak zbiorek kolejny zatytułowany Pesmi Marjana Gostiše (maj 1944). Są to wiersze powstałe w roku 1940, po rezygnacji z szentewidzkiej szkoły do wstąpienia w szeregi domobranów. Tine Debeljak tworząc Pesem naj zapojem, obydwa tomiki połączył: w miejsce tytułu Pesmice, złożone z czterech cykli: Žarki me božajo, Tesnoba teče mi skozi grlo, V usta se mi vsipljejo cvetovi, Čez obraz mi polzi kri, zaproponował Slikarski osnutek rok, podkreślając dominujący w juweniliach obrazowy, barwny ich charakter. Debeljak poczynił także parę zmian: do pierwszego cyklu dodając dwa wiersze: Presnavljanje oraz Brzojavni drogovi. Wiersz Kanal opublikowany w „Dejanju” Kocbeka, w 1940, pod tytułem Rast, Debeljak przesunął na koniec, decyzję swoją motywując, jakby pozagrobową wymową wiersza. Nieco niewielkich zmian, dotyczyło także cyklu czwartego: przeniósł dedykację na początek zbiorku, oraz wiersz Pismo, wcześniej przez Hribovška usunięty powrócił na jego dawne miejsce w zbiorku pierwszym. Tomik drugi tworzący aktualnie całość z pierwszym, poeta rozdzielił w trzy niazatytuowane cykle, co Tine Debeljak uzupełnił, nadając im tytuły zaczerpnięte $\mathrm{z}$ wierszy słoweńskiego poety: Razburkan veter mi po čelu orje (wers pochodzący z wiersza Na očetovem grobu), Prek mene je tvoja senca šla (z wiersza Psalm), V sebi sklenjen krog (z wiersza Paladi). Klamrą końcową, nowy redaktor zbiorku, uczynił wiersze Rast oraz Paladi.

Fortunat Zorman wspomina: „Takrat nisem vedel, da pesni [...] vem pa, da je imel pri sebi vedno notes, do katerega ni imel nihče dostopa" (Debeljak 1965: XIII). Nie ma wierszy Hribovška - domobrańca, jak również Balantiča strażnika, aczkolwiek o tym ostatnim wiemy, że wówczas tworzył, jak też, że wiersze się zachowały. „Kako čudno je ,prelom svetov’ razmetal in razporedil to čudovito generacijo pesnikov, kakor so bili Balantič, Hribovšek, Remic, Brejc, Šmit, pesniki enega gnezda in istih šol? Balantiča je uvrstila med vaške stražarje, Hribovška med domobrance, Remica med četnike, Brejca med partizane in Šmita v nemško vojsko! Prijatelji, ljubljenci Muz, so si stopili v nasprotje z orožjem v rokah kot borci revolucije in protirevolucije" (Debeljak 1965: XIII).

Generacja, która tak bardzo tęskniła do zmysłowej eksplozji sił witalnych stała przed „otwartymi drzwiami grobu”, śmierci wszechobecnej w poetyce każdego z tych twórców. Antyteza życie - śmierć, wszystkie ich odcienie i refleksy od narodzin, miłości, dojrzewania przez chorobę, walkę, umieranie, stanowią dominantę znaczeniową, lecz nie jedyną oś poezji Ivana Hribovška. 
Potrzeba tworzenia równoważy niejako śmiercionośny czas i jego konsekwencje, podmiot liryczny, w wierszu Paladi, prosi boginię Atenę „niech wolno mu będzie zaśpiewać pieśń”, którą nosi w sobie ,,jak we śnie”, jeśli nie niech go przeklnie:
Ali eno, Palas mi izpolni:
pesem naj zapojem, ki ko v snu
mračno nosim jo $\mathrm{v}$ iskanem dnu -
potlej mirno me za vek prekolni!
(Hribovšek 1965: 105)

Niech zaśpiewam pieśn - taki tytuł nosi tomik poezji Ivana Hribovška wydany w 1965 roku przez Słoweńską Akcję Kulturalną w Buenos Aires. Pełni on jakby podwójną rolę; ukazuje - jak pisze Debeljak - Hribovška jako poetę, jak też wybawia od przekleństwa losu - ,milczenia dwudziestu straconych lat” (T. Debeljak 1965: XIV). Stanowi on całość dorobku twórczego młodo zmarłego poety i jest jednocześnie kontaminacją dwóch przez niego samego ustanowionych całości rękopiśmiennych: Pesmic (1939) i Pesmi Marjana Gostiše (1944).

Kwestia zasadnicza dotyczyć będzie pytania: w jaki sposób, dzięki mowie wiązanej, poeta transponuje światopogląd na porządek metafizyczny. Poezja, jako metafora biografii duchowej (Sławińska 1993: 16), umożliwia agatologiczną penetrację horyzontu dobra i zła, a w nim: jednostki w relacji do Absolutu, przeżycia historycznego, miłosnego uniesienia, stworzenia (ziemi), do śmierci. Trzema pojęciami fenomenologii intersubiektywności: kategoriami spotkania, nadziei oraz wolności posłużymy się jako elementami translatorskimi eseju.

Człowiek jest istotą dramatyczną. Stajemy na scenie dramatu zadając pytanie, czy człowiek jest zdolny do wyboru między dobrem i złem? Za Tischnerem uznajemy, że „w filozofii dramatu wolność jest wolnością osoby ${ }^{5}$ postawionej pośrodku innych osób, w tym także wobec Boga" (Tishner 1991: 18). Zawsze więc istnieje w relacji Ja-Ty, w relacji do Innego, w spotkaniu z Innym. „W spotkaniu dzieje się coś ważnego, wykraczającego poza codzienność, powszedniość, normalność” (Bukowski 1987: 11) - pisze J. Bukowski. „Życie ludzkie płynie na ogół wśród zgiełku wydarzeń, sytuacji, faktów, mniej lub więcej angażujących osobę. [...] Żyję w ogromnym pośpiechu i chaosie bieżącego dnia. Jego szarość staram się rozproszyć automatyzmem rozrywki, nieautentyczność egzystencji którą wyczuwam (Heideggerowskie ,wrzucenie w świat' i ,man lebt' - ,żyje się') zastępuję pozorami autentyzmu mechanicznie spełnianych działań, brak siły woli tłumię marzeniami (,co bym zdziałał, gdyby mi się tylko chciało'), zapomnienie o wartościach, sensie, celu życia, tłumaczę sobie brakiem czasu poświęconego na realizację bieżących potrzeb. Dostrzegają to

\footnotetext{
${ }^{5}$ Osobę pojmujemy jako więcej niż podmiot, duszę, strumień czystej świadomości, ośrodek duchowego życia. Osoba stoi wobec innych osób, ale i wobec wartości. Dzięki podporządkowaniu wartościom człowiek może uzyskać wewnętrzną niezależność (wolność), w przeciwieństwie do innych form podporządkowania komuś lub czemuś niszczących jego osobowość (Bukowski 1987: 11).
} 
na równi marksiści (alienacja), psychoanalitycy (kompleksy cywilizacyjne), fenomenologowie (odejście od źródłowych doświadczeń), egzystencjaliści (technokracja), filozofowie chrześcijańscy (zapomnienie o istocie i powołaniu człowieka)" (Bukowski 1987: 19).

Dla Bukowskiego spotkanie ma zawsze charakter pozytywny inaczej niż dla Tischnera czy Węgrzeckiego, dla których możliwe jest spotkanie w horyzoncie zła, gdy ludzie wchodzą w związki oparte na nienawiści, zazdrości, zawiści. To, co Tischner i Węgrzecki nazywają wówczas spotkaniem, u Bukowskiego przestaje nim być, a staje się nienaturalnym (jeśli uznamy prawdziwość tezy o pozytywności istnienia), „wypaczeniem sensu osobowego bytu” (Bukowski 1987: 23-24). Wojnę traktować będziemy jako scenę dramatu spotkania człowieka z innymi i Bogiem w horyzoncie dobra i zła, w obu przypadkach mówić będziemy o spotkaniu.

Wolność zakłada z jednej strony wolność osoby w stosunku Boga, do innych, jak też, wolność w stosunku do siebie. „Osoba - podmiot dramatu, pisze polski filozof - jest ,rozpięta' między przeciwieństwami. Dobro i zło pojawiają się na linii jej odniesień do innych osób: Boga, ludzi a także na poziomie odniesień do samej siebie. [...] Problemem podstawowym osoby jest problem usprawiedliwienia i potępienia. Zło zasługuje na potępienie. Dobro [...] na usprawiedliwienie. Człowiek ,pragnie' uniknąć potępienia i zasłużyć na ,usprawiedliwienie'. Jednym z podstawowych pytań człowieka jest: czy jest wolny w wyborze dobra i zła?” (Tishner 1991: 99) „Być wolnym w stosunku do innych, znaczy: móc się wyzwolić spod ich przemocy" (Tishner 1991: 19). Co nabiera szczególnego znaczenia w „czasie kalekim”, gdy idea nadczłowieka z jednych czyni „panów”, zdecydowanych przemocą podporządkować sobie słabszych, wówczas wolność wydaje się być kategoryzowana inaczej, domagając się wyznaczenia jej granic.

Wolność natomiast możliwa jest dzięki bardzo starej sztuce, która „ma kolosalną przyszłość" - dzięki myśleniu, gdyż jak pisze Tischner w innym miejscu swej rozprawy: „kluczem do niewolnictwa nie jest pytanie kto stchórzył, a kto zdobył się na odwagę, lecz kto przestał a kto zaczął myśleć. [...] Być wolnym, to nie znaczy być panem lub niewolnikiem, odnajdywać siebie w takiej lub innej sytuacji, we wnętrzu strumienia życia, lecz zachowywać się jako byt myślący we wszystkich okolicznościach życia" (Tishner 1993: 53-54).

Wolność Tischner widzi tak w horyzoncie dobra, jak w horyzoncie zła. Za krakowskim filozofem uznajemy, iż: „egzystencja ludzka na tym polega, że w człowieku dobro i zło poprzedzają istnienie. Człowiek ,bardziej jest', gdy bardziej staje się dobrym, ,jest mniej' i zapada w nicość [...], gdy staje się złym" (Tishner 1991: 121). W horyzoncie zła jawi się największy ból egzystencjalny, jest to ból wyrażający obecność zła. W horyzoncie dobra, jako „siła przyswajania" - jak ją nazywa - służy ona przyswajaniu dobra osobie i osobę dobru. Przykłady tych dóbr to prawdomówność, sprawiedliwość, wierność, poświęcenie. „Kirkeegord - jak pisze Tischner - mówi o ,wartości absolutnej’, absolutny pochodzi zaś od absolvere - ,rozwiązywać'. Wolność więc coś ,rozwiązuje' i do czegoś ,przywiązuje' - ,odswaja' i ,przyswaja"” (Tishner 1998: 
316). Ponieważ jest zawieszona pomiędzy konkretem i ideałem nie stanowi według krakowskiego filozofa wartości najwyższej.

„Przejście od uwięzienia do wolności pociąga za sobą swoistą przemianę przeżyć. Oto znikają doznania i przeżycia charakteryzujące stan uwięzienia przeżycia lęku, melancholii, smutku, beznadziei i rozpaczy - a na ich miejsce pojawia się radość, pewność, nadzieja. Szczególne znaczenie ma tu nadzieja. Wolność jest mocą wyzwalającą nadzieję. Wyzwala ona także radość i poczucie godności” (Terlecki 1987: 317). Wolność i nadzieja pozostają w ścisłym, wprost proporcjonalnym związku. Skąd to szczególne waloryzowanie nadziei? Dla Kocbeka: „Wszystko, co jest naprawdę ważne w życiu na ziemi da się zamknąć w dwóch słowach: człowiek człowiekowi. Bliźni to najwyższe, najtrudniejsze i najbardziej tajemnicze zadanie" (Kocbek 1967: 424) (człowiek jest nam zadany), i dodaje ,stosunek do bliźniego jest w życiu chrześcijanina równie ważny jak stosunek do samego Boga" (Kocbek 1967: 279). Postawa Kocbeka koresponduje z przekonaniami Mouniera, który twierdzi, iż: „Osoba istnieje tylko zwracając się ku drugiemu człowiekowi, tylko poprzez drugiego człowieka może siebie odnaleźć" (Mounier 1964: 37). Fascynację młodego poety budzili obydwaj poeta - myśliciel i filozof, z tego powodu pozostawał pod wpływem ich filozofii. Podzielając pogląd Tischnera, iż nasza (własna) nadzieja jest najwłaściwszą perspektywą odkrywania i oglądania prawdy: prawdy o chrześcijaństwie, o człowieku, o naszym świecie, a nawet o śmierci, poszukiwać będziemy realizacji powyższej tezy w poetyce Hribovška. To właśnie dzięki nadziei możliwe staje się w niej „przezwyciężenie śmierci”:

umrl sem breznom, dolinam,

strasti so ostale na dnu,

večno bom živel širinam,

ki so preproga Bogu

(Hribovšek 1965: 27)

tego rodzaju „zwycięstwo” stało się udziałem także i słoweńskiego poety.

„Chyba każdy zgodzi się z tym, że żadnego z wybitniejszych poetów pokolenia okupacyjnego nie można dziś czytać, abstrahując od jego żołnierskiego i konspiracyjnego życiorysu. Nieusuwalną przyczyną tej szczególnej czytelniczej przypadłości jest ich tragiczna śmierć. Ale i życie napięte do ostatecznych granic w przeżywaniu świata, historii, ojczyzny, sztuki i wreszcie samych siebie stanowi dostateczną rację, aby naszą uwagę dzielić między ich poezję a biografię" (Świegocki 1985: 107). Z K. Świegockim dzielimy przekonanie, ze los poety, poszczególne tropy biografii śledzić możemy w poetyce tak immanentnej jak i sformułowanej jego twórczości. „Twarz poety” rozpoznajemy

${ }^{6}$ „Jedynym dzisiaj kryterium odróżnienia dobrego poety od setki miernych kopistów nie są bowiem, jak dawniej rygory rzemiosła, lecz twarz poety [...] osobowość poetycka i los - rzecz spoza samej poezji. Jedynym uchwytnym gwarantem zaś - szczerość, właściwość moralna. I cena, którą poeta zapłacił za wiersz, a więc, w ostateczności sprawa biografii" (Wat 1990: 249). 
w dramacie jednostki po Heideggerowsku „wrzuconej” w wir historii, jak też jednostki - immanentnej części pokolenia, którego „swoiste przeżycie czasu” (Wyka 1976: 62) wyryło piętno w duszy artysty. Przeżycie doświadczenia pokoleniowego prześledzić należy w tematach - obrazach, jak: ziemia, Bóg, miłość, życie, śmierć., powracających w twórczości poetyckiej Ivana Hribovška.

Wydobycie z ,grobu niepamięci” poezji i poetów przemilczanych i włączenie jej do kanonu poezji słoweńskiej, pozwoliło odzyskać słoweńskiej świadomości poetyckiej pełnię własnej tożsamości. Historykom pozostawiamy los Hribovška - żołnierza, oraz problematykę ideologicznej „zdrady”, los z pewnością wart, by zajął się nim kompetentny badacz. Nasz podziw budzi raczej „dojrzałość” tych dwudziestolatków, zadziwiają poziomem myśli, dojrzałością formy, dlatego podzielamy opinię K. Świegockiego, iż „nie jest [ich liryka] bynajmniej dziś jedynie czcigodnym zabytkiem, wzruszającą pamiątką tamtych ,krwawych lat', lecz żywym źródłem inspiracji. Elektryzuje [...] nie tylko niezwykłą spontanicznością i sugestywnością języka plastycznego, wyrazistego, a zarazem jasnego i logicznego (cnoty jakże dziś rzadkie!), ale problematyką i zarysowanymi - bo nie rozwiniętymi jeszcze - propozycjami rozstrzygnięć ideowych" (Świegocki 1985: 108). Wypowiedź uczonego komentująca twórczość dwóch wielkich polskich poetów tego okresu, Baczyńskiego i Gajcego w zadziwiająco trafny sposób koresponduje z zakresem problematyki dotyczącej tragicznych postaci słoweńskiego dramatu wojennego, w istocie dotyczy więc także Ivana Hribovška i jego „towarzyszy pióra i broni”.

\section{LITERATURA}

Balantičev in Hribovškov zbornik. Ur. Marjan Dolgan. Ljubljana, Celje, 1994.

Biblia Tysiąclecia Red. nauk. O. A. Jankowski. Poznań, 1979.

Jacek BUKOWSKI, 1968: Zarys filozofii spotkania. Kraków.

Tine DEBELJAK, 1965: Pesmi Ivana Hribovška. Glas SKA XII.

Ivan HRIBOVŠEK, 1965: Pesem naj zapojem. Buenos Aires.

- -, 1990: Pesmi. Ljubljana.

- -, 1993: Himna večeru. Celje.

Edvard KOCBEK, 1967: Listina. Ljubljana.

Edward MADANY, 1982: Jugosłowiański Bóg Mars. Łódź.

Henryk MARKIEWICZ, 1976: O „Pokoleniach literackich” Kazimierza Wyki. Twórczość 7.

\footnotetext{
${ }^{7}$ Oprócz I. Hribovška, mamy także na myśli Balantiča, Brejca, Remica i innych poległych w wielkiej wojnie młodych poetów słoweńskich.
} 
Emanuel MOUNIER, 1964: Wprowadzenie do egzystencjalizmów. Kraków.

France PIBERNIK, 1993: Vrnitev iz tišine. I. Hribovšek: Himna večeru. Celje. - -, 2010: Ivan Hribovšek. Monografija. Ljubljana.

Joanna PSZCZOŁA, 2011: Tajemnica transcendencji. Duchowość poezji Ivana Hribovška. Bielsko-Biała.

Kazimierz ŚWIEGOCKI, 1985: Poezja i czyn. Poezja 5/6, 107-108.

Joanna SŁAWIŃSKA, 1993: Poetyckiej kosmogonii Edvarda Kocbeka. Kraków.

Tadeusz TERLECKI, 1987: Egzystencjalizm chrześcijański. Krytyka personalistyczna. Egzystencjalizm chrześcijański. Warszawa.

Józef TISCHNER, 1998: Spór o istnienie człowieka. Kraków.

- -, 1993: Spowiedź rewolucjonisty. Kraków.

--, 1991: Zarys filozofii człowieka. Filozofia człowieka dla duszpasterzy i artystów. Kraków.

Aleksander WAT, 1990: Dziennik bez samogłosek. Warszawa.

Kazimierz WYKA, 1976: Problematyka pokoleń literackich. Twórczość 7, 62.

\section{O PESNIKOVEM HREPENENJU}

Misli, ki jih je zašepetal Ivan Hribovšek

Članek se osredinja na poezijo zamolčanega slovenskega vojnega pesnika, Ivana Hribovška. Njegova "poezija zorenja« (pesniti je namreč začel pri šestnajstih letih, že pri dvaindvajsetih letih pa je umrl nasilne smrti) je izredno dognana in močna, kar je opazil že Tine Debeljak, ki ima velike zasluge za prvo izdajo Hribovškovega opusa v zbirki Pesem naj zapojem (izšla je v Buenos Airesu leta 1965).

Pesnik je bil v domovini dolga leta nepreklicno obsojen na izgnanstvo iz domačega kulturnega prostora. Kot domobranski vojak je postal žrtev pozabe, hkrati pa je bilo pozabljeno tudi njegovo pesniško delo (sicer politično nezaznamovano). Šele leta 2010 dobimo Pibernikovo monografijo o pesniku in Hribovškovo Zbrano delo. Problematika domobranstva in pesnikove udeležbe $\mathrm{v}$ njem je zelo pomembna, a jo je bolje prepustiti zgodovinarjem. Obravnavana poezija, ki jo lahko označimo kot »čisto« (čeprav ne v bremondovskem smislu), vsebuje čisto ljubezen v weilovskem pomenu, hkrati pa je izraz navdihovanja z Absolutom, ki je Lepota sama. Čistost Hribovškove poezije pomeni čistost duhovne lirike, brez vsake ideologije. Izrecno jo zaznamuje spiritualizem lirske izpovedi. Njen subjekt presenetljivo iskreno in sugestivno izraža svoja globoka, tenkočutna in niansirana duhovna doživetja. Pojmovni svet Hribovškove lirike tako odpirajo naslednje kjučne besede: zemlja, Bog, življenje, smrt, ljubezen. 